\title{
TUNTUTAN FASAKH: KAJIAN DARI PERSPEKTIF UNDANG-UNDANG TATACARA MAL
}

\section{Fasakh Proceedings: A Study from Perspective of Shariah Courts Civil Procedure}

\author{
MohdZaidiMdZain@Zakaria \\ Ph.D Candidate, Department of Shariah and Law, \\ Academy of Islamic Studies, \\ University of Malaya, 50603 Kuala Lumpur. \\ dmzaidizain@hotmail.com \\ Raihanah Hj. Abdullah \\ Professor, Department of Shariah and Law, \\ Academy of Islamic Studies, \\ University of Malaya, 50603 Kuala Lumpur. \\ raihanah@um.edu.my
}

\begin{abstract}
This article focuses on the fasakh proceedings from the perspective of the civil procedure that have been adopted in the Shariah Courts in Malaysia, in terms of advantages and disadvantages to identify fairness and efficiency in speeding up the fasakh trials without compromising the principles of Islamic jurisprudence and justice in case judgment. This study shall focus on some of the provisions of the civil procedure that contribute to the delay in fasakh proceedings with particular reference to the Shariah Courts Civil Procedure Enactment of Selangor 2003; as representing all the other states in Malaysia. These provisions include the summon delivery process, jurisdiction of the courts, the trials and the appeals. This article has shown that the provisions of the civil procedures needed to be improved so as to ensure that fasakh cases could be expedited in a short period of time.
\end{abstract}

Keywords: fasakh, Shariah Civil procedure, Shariah Courts, divorce 


\section{PENDAHULUAN}

Fasakh adalah satu daripada hak suami isteri yang termaktub di dalam undangundang substantif berdasarkan kepada peruntukan undang-undang keluarga Islam setiap negeri di Malaysia. ${ }^{1}$ Hak ini telah disebut dengan jelas dan hampir keseluruhan alasan yang diperuntukkan adalah melibatkan kesalahan di pihak suami yang boleh mengakibatkan pengabaian, penganiayaan dan kezaliman kepada isteri. Tidak keterlaluan jika dikatakan bahawa fasakh adalah jalan terakhir yang terpaksa dipilih oleh seseorang isteri yang tidak lagi dapat meneruskan kehidupan bersama dengan suaminya. Ini kerana bentuk-bentuk perceraian yang lain seperti talaq, khulu' dan ta 'liq ${ }^{2}$ tidak dapat diperoleh melainkan dengan persetujuan suami semata-mata.

Oleh kerana fasakh adalah kuasa hakim untuk membubarkan perkahwinan tanpa lafaz dan kebenaran dari suami, maka pihak isteri hendaklah mengemukakan bukti kukuh untuk meyakinkan Hakim Bicara bahawa alasanalasan untuk sabitan fasakh tersebut adalah benar dan menepati kehendak Syarak. Dalam masa yang sama, suami juga akan diberi ruang yang saksama untuk membela diri di atas pertuduhan yang dikemukakan oleh pihak isteri.

Namun begitu, prinsip keadilan dalam perbicaraan kes tidak hanya terhad kepada memberi peluang samarata kepada pihak-pihak untuk mengemukakan keterangan dan pembuktian, tetapi juga mengambil kira tempoh masa yang munasabah bagi menyelesaikan sesuatu kes yang dibicarakan. Ini kerana tempoh masa yang panjang merupakan penafian keadilan kepada pihak yang berhak sebagaimana kaedah undang-undang ${ }^{3}$ yang menyebut bahawa keadilan yang tertangguh adalah keadilan yang dinafikan. Kelewatan dalam perbicaraan kes juga akan mengakibatkan berlakunya 'backlog cases' iaitu kes-kes tertangguh atau tertunggak yang menampakkan keadilan telah tidak diuruskan dengan sewajarnya. Sedangkan keadilan itu bukan sekadar melaksanakannya, tetapi ia mestilah dilihat sebagai telah dilaksanakan. ${ }^{4}$

1 Lihat seksyen 52 atau 53 Enakmen Undang-undang Keluarga Islam negeri di seluruh Malaysia.

2 Ketiga-tiga jenis perceraian tersebut memerlukan persetujuan atau lafaz daripada suami berdasarkan kepada hukum asal perceraian hanya dibenarkan dilafazkan oleh pihak lelaki sebagaimana surah al-Baqarah ayat 229 dan 236.

3 Dalam Bahasa Inggeris, kaedah undang-undang tersebut berbunyi: Justice delayed is justice denied.

4 Dalam Bahasa Inggeris, legal maxim tersebut berbunyi: Justice must not be done; it must also be seen to be done. 
Laporan dan aduan mengenai kelewatan kes perceraian termasuk kes fasakh sering kedengaran di media cetak, elektronik serta media alternatif. Pelbagai usaha telah dilakukan oleh pihak berwajib untuk mengatasi masalah tersebut seperti membuat pindaan kepada undang-undang mahkamah Syariah bermula sejak awal tahun $2003^{5}$ dan yang terbaru ialah pelaksanaan perceraian secara fast track di Mahkamah Syariah Negeri Selangor. ${ }^{6}$ Namun begitu, ia tidak menyelesaikan masalah sebenar yang diadukan iaitu berkaitan dengan kelewatan perjalanan proses perbicaraan di mahkamah.

Berdasarkan kepada kajian dan penulisan yang dibuat sebelum ini, terdapat banyak faktor yang menyumbang kepada kelewatan kes di Mahkamah Syariah, dan salah satu daripada faktor tersebut adalah berkaitan dengan undang-undang prosedur (Raihanah Hj, Abdullah, 2009: 17-19). Raihanah $\mathrm{Hj}$. Abdullah dalam kajiannya di Mahkamah Syariah Wilayah Persekutuan Kuala Lumpur menyimpulkan antara lain faktor yang menyumbang kepada kelewatan kes ialah berkait dengan undang-undang prosedur. Undang-undang prosedur merujuk kepada proses penyampaian saman, di mana berdasarkan peruntukan seksyen 7 (1) Akta Tatacara Mal Mahkamah Syariah (Wilayahwilayah Persekutuan) $1998,{ }^{7}$ prosiding kes hendaklah dimulakan dengan saman yang kemudiannya hendaklah disampaikan dengan sempurna kepada pihak defendan. Sekiranya proses penyampaian saman tidak dilakukan dengan sempurna, maka ia akan mengambil masa antara dua hingga empat bulan atau dua kali sesi kehadiran ke mahkamah, sedangkan perkara asas tuntutan belum bermula.

Jika di peringkat penyampaian saman telah mengambil masa yang panjang, bagaimana dengan proses selepas saman disempurnakan? Adakah peruntukan Undang-undang Tatacara Mal yang ada sekarang telah memudahkan proses perjalanan kes selepas penyampaian saman disempurnakan? Ini kerana proses pengurusan kes seperti penyempurnaan pliding dan ikatan dokumen juga telah

$5 \quad$ Pindaan-pindaan tersebut berdasarkan kepada cadangan penyeragaman undangundang Mahkamah Syariah seluruh Malaysia yang dipersetujui oleh Majlis RajaRaja pada 1 Ogos 1997.

6 Proses kes cerai fast track yang dilancarkan oleh Mahkamah Syariah Negeri Selangor pada 9 Julai 2015 hanyalah melibatkan kes perceraian secara persetujuan bersama sahaja yang dahulunya mengambil masa selama dua hingga empat minggu, tetapi melalui proses ini kes perceraian boleh diselesaikan dalam tempoh enam jam sahaja.

7 Akta tersebut memperuntukkan bahawa "(1) Tertakluk kepada subseksyen (2) atau mana-mana undang-undang bertulis lain, tiap-tiap prosedur Mal hendaklah dimulakan dengan saman. Setiap prosiding berkenaan dengan mana-mana perkara yang dinyatakan dalam jadual kedua hedaklah dimulakan dengan permohonan”. 
memakan masa antara dua hingga empat bulan melibatkan dua hingga tiga kali sesi kehadiran ke mahkamah. Selanjutnya proses perbicaraan jika mengikut prosedur yang sedia ada, kes yang perlu disegerakan seperti tuntutan fasakh ini akan turut sama mengalami proses yang panjang dan memenatkan kerana mengambil masa bertahun untuk diselesaikan. Jika perkara ini tidak diatasi, maka ia pasti akan mendatangkan kemudaratan yang lebih besar ke atas isteri kerana terpaksa menanggung duka yang berganda akibat penganiayaan oleh suami yang tidak bertanggungjawab, sekali gus menjadi fitnah kepada sistem perundangan Syariah di negara ini.

Sebagaimana yang telah sedia maklum bahawa undang-undang keluarga Islam yang diamalkan di negara ini telah melalui beberapa siri pindaan yang melibatkan penambahan dan pemansuhan peruntukan tertentu, selari dengan tuntutan dan perubahan semasa yang berlaku di dalam masyarakat. Namun begitu, masih lagi timbul isu kurang puas hati khususnya dalam kalangan wanita terhadap beberapa aspek undang-undang keluarga Islam yang melibatkan soal prosedur dan pengurusan kes mahkamah, khususnya berkaitan dengan tuntutan fasakh. Rungutan-rungutan seperti kes terlalu lama dibicarakan, berlaku penangguhan yang tidak wajar, pemakaian prosedur yang terlalu ketat dan sebagainya telah menjadi perbualan yang biasa didengar.

Keadaan ini telah menimbulkan persoalan dalam kalangan masyarakat apakah telah berlaku penganiayaan secara sah terhadap wanita kerana terpaksa mengharungi proses perbicaraan yang begitu menyeksakan serta menanggung penderitaan zahir dan batin yang terlalu lama bagi menamatkan perkahwinan yang tidak memberi erti lagi. Sedangkan di pihak suami, telah terakru hak dan keistimewaan berlandaskan undang-undang serta hukum Syarak dalam menentukan kedudukan dan ikatan perkahwinan mereka tanpa melalui prosedur yang sama. Tan Sri Dato' Haji Lamin Haji Mohd Yunus, sewaktu memegang jawatan Presiden Mahkamah Rayuan Malaysia pernah berkata, kadangkala bidang prosedur ini berkehendakkan kajian yang mendalam agar ianya tidak menjadi rintangan dalam proses mencapai keadilan. Jadi kefahaman dan penjelasan perlu diberi bukan sahaja terhadap undang-undang keluarga tetapi juga bidang prosedurnya (Abdul Monir Yaacob, 2000: 9).

\section{KAJIAN-KAJIAN LEPAS}

Persoalan fasakh sebenarnya amat luas dan ianya bukan berlegar di sekitar isu, sebab dan alasan sahaja, tetapi juga mencakupi persoalan undang-undang disebabkan perceraian fasakh hanya boleh disabitkan melalui perintah mahkamah. Sekiranya persoalan undang-undang ini tidak dipatuhi maka boleh menyebabkan tuntutan fasakh menjadi sukar dan tidak kurang juga ditolak oleh 
mahkamah. Situasi ini sebenarnya menjadikan kajian mengenai kelewatan kes fasakh amat wajar dibuat secara berterusan, selari dengan perkembangan dan perubahan semasa yang berlaku. Tinjauan semula ini cuba meneliti beberapa kajian dan penulisan yang telah dihasilkan mengenai fasakh dari segi skop dan pendekatan penulisan-penulisan tersebut.

Kebanyakan skop atau pendekatan penulisan artikel yang dihasilkan mengenai fasakh lebih tertumpu kepada aspek sebab dan alasan kewajaran untuk membubarkan perkahwinan secara fasakh. Misalnya penulisan artikel oleh Tan Sri Ahmad Ibrahim (1978: 329) yang telah menyentuh mengenai alasan kegagalan suami menyara dan menafkahkan isteri sebagaimana tuntutan Syarak boleh mengakibatkan mahkamah menjatuhkan hukuman fasakh ke atas perkahwinan tersebut. Manakala di dalam artikel yang ditulis oleh Mehrun Siraj (1989: 2) telah membincangkan mengenai pendekatan baru alasan-alasan yang membolehkan seorang isteri memohon fasakh. Kajian tersebut mengambil kira dari aspek yang lebih luas bukan sahaja soal pengabaian terhadap pemberian nafkah, tetapi juga merangkumi semua aspek penganiayaan yang mengakibatkan kehidupan isteri menderita dari segi mental dan fizikal.

Di dalam artikel yang ditulis oleh Raihanah Haji Abdullah (1997: 51-62) pula telah memperincikan lagi mengenai alasan-alasan yang membolehkan seseorang isteri mengemukakan tuntutan fasakh di Mahkamah Syariah sebagaimana yang diperuntukkan di dalam undang-undang keluarga Islam dan dalil-dalilnya berdasarkan hukum Syarak. Beliau juga telah membawa perbahasan dan perbezaan pendapat dalam kalangan para ulama silam mengenai alasan-alasan yang membolehkan fasakh, perbahasan dan huraian yang mendalam di dalam artikel ini telah menyimpulkan bahawa prinsip dari mazhab Maliki dan Shāfi'ī mengenai alasan-alasan fasakh telah mendominasikan peruntukan fasakh di kebanyakan negara umat Islam semenjak zaman kerajaan Turki Uthmaniyyah lagi. Prinsip-prinsip tersebut juga telah mempengaruhi pemakaiannya di Malaysia bermula pada zaman kerajaan Melayu Melaka dan kemudiannya telah diperkemaskan pemakaiannya sehingga ke hari ini.

Selain daripada itu, banyak kajian disertasi yang berkaitan dengan fasakh telah ditulis yang juga menumpukan kepada skop alasan-alasan fasakh tetapi merujuk kepada peruntukan Enakmen atau Akta Undang-undang Keluarga Islam di negeri-negeri yang berbeza. Misalnya penulisan Noor Hayati Aripin (1992) yang telah membincangkan mengenai alasan-alasan fasakh yang terdapat secara khusus di dalam peruntukan Undang-undang keluarga Islam di Malaysia dengan tumpuan diberikan kepada Enakmen di Negeri Pahang. 
Di akhir kajian tersebut dimasukkan sepintas lalu perbincangan mengenai prosedur permohonan fasakh yang diamalkan di negeri tersebut.

Manakala di dalam disertasi Amalina Husain (1993) membincangkan tentang alasan-alasan fasakh yang boleh dikemukakan oleh isteri sebagaimana diperuntukkan di dalam Enakmen Undang-undang Keluarga Islam Kelantan. Manakala di akhir kajian ini, penulis telah membuat kesimpulan tentang sama ada alasan-alasan yang diperuntukkan tersebut memerlukan kepada kajian semula bagi memastikan kesesuaiannya dengan perubahan masa yang berlaku.

Berdasarkan kajian Salmah Ahmad (1999) pula yang menghuraikan tentang alasan-alasan fasakh dan prosedur tuntutan yang harus dibuat oleh wanita di Wilayah-Wilayah Persekutuan. Pendekatan yang sama juga digunakan oleh Hadrah Layabo (2002) dalam kajian beliau di Kota Kinabalu, Sabah. Begitu juga dengan kajian yang dijalankan oleh Arip Ameran (2000) yang mengkaji alasan-alasan perceraian secara fasakh di Mahkamah Sarawak khususnya di Kuching.

Kecenderungan untuk membuat kajian di setiap negeri mengenai alasanalasan fasakh telah menjadi satu ikutan bagi penulisan ilmiah di mana Norizan Othman (2008) telah menyentuh mengenai alasan dharar yang telah diputuskan oleh Mahkamah Syariah Melaka bagi memfasakhkan perkahwinan.

Pendekatan yang sama juga digunakan di dalam penulisan Nurhidayah Muhd Hashim (2001) yang membincangkan mengenai tuntutan fasakh. Buku ini antara lain mengupas mengenai hukum perceraian fasakh dan dalil-dalilnya serta alasan-alasan kepada tuntutan fasakh di dalam peruntukan undangundang keluarga Islam di Malaysia dengan merujuk kepada kes-kes yang berkaitan. Di hujung perbincangan, buku ini turut menyentuh tentang prosedur tuntutan fasakh yang diamalkan di Mahkamah Syariah di Malaysia.

Dari aspek pembuktian, tidak banyak penulisan yang dibuat dengan menyentuh secara khusus berkaitan dengan tuntutan fasakh. Hal ini kerana kebanyakan penulisan yang membicarakan aspek pembuktian dibuat secara umum yang menyentuh keseluruhan tuntutan dan pendakwaan. Kebiasaannya perbincangan-perbincangan tersebut dilakukan di bawah bab al-da'wa, bab al-qada', bab al-syahadah, bab iqrar, bab qarinah, dan al-bayyinah. Namun begitu, terdapat beberapa kajian disertasi telah dibuat secara khusus mengenai tuntutan fasakh, antara lain oleh Zaliha Safee (2000) dan juga Rafidah Sulaiman (2003). Kedua-dua kajian ini menyentuh mengenai kaedah-kaedah pembuktian yang digunapakai di mahkamah-mahkamah terbabit untuk mensabitkan perceraian fasakh. Kedua-dua penulis ini merujuk kepada hukum Syarak serta akta dan enakmen undang-undang keterangan negeri masing-masing sebagai 
rujukan perundangan untuk mengulas persoalan pembuktian yang perlu diketengahkan oleh isteri-isteri yang memohon fasakh di mahkamah.

Terdapat satu kajian disertasi oleh Wan Haslina Wan Ab Kadir (2007: 1-50) yang mengupas penggunaan qarinah di dalam tuntutan fasakh di Mahkamah Rendah Syariah Kota Bharu. Beliau mendapati bahawa penggunaan qarinah di mahkamah tersebut melibatkan qarinah yang berbentuk dokumen dan fakta yang berlainan yang boleh dijadikan alasan untuk mensabitkan fasakh. Manakala qarinah yang betul-betul diaplikasikan oleh Hakim ialah qarinah berbentuk dokumen, secara keseluruhannya, kajian menunjukkan bahawa pembuktian berdasarkan qarinah tidak berdiri dengan sendirinya tanpa pembuktian yang lain seperti shahadah dan bayyinah.

Selanjutnya dari aspek undang-undang prosedur, penulis mendapati kebanyakan kajian dan penulisan yang mengupas mengenai undang-undang tersebut secara menyeluruh dan tidak memfokuskan isu berbangkit daripada pengamalannya yang mengakibatkan kelewatan kepada perbicaraan kes. Manakala menurut kajian Mahmud Saedon Awang Othman (1990: 1-24), beliau telah menganalisa keseluruhan undang-undang Acara Mal yang diterimapakai di seluruh negeri di Malaysia selepas terpindanya Perlembagaan Persekutuan ${ }^{8}$ yang menegaskan bahawa Mahkamah Awam tidak mempunyai bidangkuasa berkenaan dengan apa-apa perkara dalam bidangkuasa Mahkamah Syariah.

Berikutan kepada pindaan tersebut, Mahkamah Syariah memerlukan undang-undang acara yang khusus, kemas dan lebih terperinci berbanding dengan peruntukan-peruntukan sebelumnya yang tidak lengkap dan bercampur baur dengan undang-undang substantif dan keterangan. Beliau telah meletakkan Draf Rang Undang-undang Acara Mal Mahkamah Syariah Wilayah Persekutuan 1989 sebagai model terbaik pada masa itu ke arah penyelesaian masalah-masalah yang berbangkit daripada lakuna yang ada dalam undangundang yang digunapakai sebelumnya sehingga beliau menyifatkan undangundang Acara Mal tersebut sebagai Acara Mal Islam.

Manakala dalam penulisan Mohd Raziff Tan Sri Zahir (1998: 128-142), telah menyentuh berkenaan dengan perbezaan-perbezaan prosedur tuntutan Mal di negeri meliputi isu dan permasalahan secara umum. Beliau juga membangkitkan beberapa permasalahan dalam peruntukan undang-undang prosedur mal dari sudut amalan khususnya penyediaan pliding, kaedah permohonan ex-parte, pemakaian afidavit dan prosiding interlokutori.

Mohd Zaidi Md Zain (2000: 194-204) dalam kajian beliau telah membincangkan secara terperinci tentang peruntukan-peruntukan yang

\footnotetext{
$8 \quad$ Akta Perlembagaan (Pindaan) 1998 (Akta A 704) Perkara 121.
} 
terdapat di dalam Enakmen Prosedur Mal Negeri Selangor dengan membandingkan ketepatan dan keselarian dengan hukum Syarak. Di dalam kajian tersebut, beliau mendapati bahawa keseluruhan peruntukan mengenai proses pra-perbicaraan termasuklah penyediaan pliding, pemfailan kes, kaedah penyampaian saman sehingga kepada perbicaraan dan pasca perbicaraan adalah menepati kehendak hukum Syarak berdasarkan kepada prinsip-prinsip kaedah fiqhiyyah dan sumber hukum dari al-Quran dan hadis.

Selanjutnya Suwaid Tapah (2005: 23-24) telah menghasilkan satu kajian tentang kelemahan peruntukan undang-undang tatacara mal di Mahkamah Syariah secara menyeluruh. Kajian tersebut juga membincangkan kesan-kesan kelemahan prosedur dan pelaksanaannya ke atas kes-kes yang dibicarakan termasuklah isu kelewatan dan kesulitan yang dihadapi oleh pihak-pihak yang bertikai di mahkamah. Kajian tersebut merujuk kepada kes-kes sekitar tahun 2000 selaras dengan pindaan undang-undang tatacara mal di kebanyakan negeri yang bermula pada awal tahun 2000 .

Kajian terkini mengenai prosedur mal telah ditulis oleh Mohd Nadzri Haji Abdul Rahman Ibrahim (2013: 22-23) yang telah memperkenalkan undangundang prosedur mal dengan nama Undang-undang Tatacara Mal Mahkamah Syariah selepas pindaan terbaru pada tahun 2003 di Negeri Sembilan. Kajian tersebut bertujuan untuk membincangkan kehendak-kehendak undang-undang tatacara mal dan amalannya di Mahkamah Syariah. Perbincangan dimulai dengan proses pra perbicaraan yang merangkumi penyediaan borang saman dan permohonan, serta tatacara penyampaian dokumen-dokumen tersebut.

Seterusnya, penulis membincangkan juga berkenaan dengan prosedur sewaktu dan selepas perbicaraan termasuklah prosiding interlokutori, ex parte, injunksi, penguatkuasaan, penghinaan mahkamah dan sebagainya. Namun begitu, kajian ini tidak menyentuh mengenai kesan ke atas pengendalian kes akibat kelemahan yang terdapat di dalam undang-undang tatacara mal tersebut.

Manakala dalam isu kelewatan kes di Mahkamah Syariah, terdapat beberapa penulisan dan kajian yang dibuat. Antara lain ialah kajian sekumpulan penyelidik yang diketuai oleh Ahmad Hidayat Buang (2003: 6) yang mengklasifikasikan tempoh-tempoh masa yang dikategorikan sebagai melebihi tempoh masa yang munasabah untuk sesuatu kes diselesaikan. Kajian tersebut melibatkan kes-kes perceraian termasuklah fasakh dan juga kes-kes tuntutan lain seperti nafkah isteri, nafkah anak, nafkah 'iddah, harta sepencarian, mut'ah dan hadānah. Bagi kes perceraian, tempoh masa melebihi satu tahun dikategorikan sebagai lewat. Manakala, bagi tuntutan lain selepas perceraian yang melebihi dua tahun adalah diklasifikasikan sebagai lewat. 
Berbeza dengan dapatan yang diperolehi oleh Nik Roslina Raja Ismail (1999: 47-48) dalam kajiannya yang mendapati bahawa penyelesaian bagi kes Mahkamah Syariah mengambil masa selama enam bulan.

Dalam kajian Zaleha Kamaruddin (2001:38) terhadap kes-kes penangguhan di mahkamah antara tahun 1990-1997 menyimpulkan bahawa antara punca kelewatan kes adalah kerana beban tugas yang tidak selari dengan jumlah Hakim yang ditugaskan untuk mengendalikan kes-kes tersebut. Kajian tersebut merangkumi keseluruhan kes-kes di bawah bidangkuasa Mahkamah Syariah iaitu kes-kes pernikahan, perceraian dan tuntutan selepas perceraian. Namun begitu, kajian tersebut tidak menyentuh secara khusus isu-isu prosedural yang mengakibatkan penangguhan kes-kes di Mahkamah Syariah.

\section{TUNTUTAN FASAKH DARI PERSPEKTIF UNDANG-UNDANG SUBSTANTIF}

Daripada penelitian yang dibuat, penulis mendapati bahawa penyeragaman peruntukan undang-undang mengenai alasan-alasan fasakh telah tidak memberikan perbezaan yang besar kepada tempoh penyelesaian tuntutan fasakh di Mahkamah Syariah. Ini kerana alasan-alasan yang diperuntukkan sebelum penyelarasan tersebut telah dipadankan dengan permasalahan yang berlaku dalam hubungan suami isteri. Paling tidak, alasan syiqaq berpanjangan yang berlaku dalam hubungan perkahwinan telah memadai dijadikan alasan utama dalam keadaan di mana pihak isteri tidak dapat mengemukakan bukti yang kukuh mengenai alasan-alasan yang lain. Ini disebabkan peruntukan sebelum dan selepas penyelarasan tersebut menghendaki plaintif membuktikan sekurang-kurangnya satu sahaja alasan daripada alasan-alasan yang disenaraikan itu.

Sebagaimana kes Zulriana Zahari lwn. Mohd Shu'aib Hj. Ishak di mana dalam kes tersebut, Mahkamah Rayuan Syariah telah meluluskan permohonan rayuan fasakh pihak perayu atas alasan pihak responden tidak memberikan nafkah selama tempoh melebihi tiga (3) bulan. Antara isu yang dibangkitkan dalam kes ini adalah semasa di peringkat Mahkamah Bicara, pihak perayu telah gagal untuk membuktikan keempat-empat alasan fasakh sehingga menyebabkan tuntutannya ditolak oleh Hakim Bicara. Walau bagaimanapun, Y.A.A. Hakim Mahkamah Rayuan telah mengulas bahawa kaedah pentafsiran statut yang dominan bagi sesuatu peruntukan undang-undang yang ringkas dan jelas adalah berdasarkan kaedah pentafsiran berdasarkan makna harfiah (literal approach).

9 Zulriana Zamri lwn. Mohd Shu'aib Haji Ishak [2014] JH 38/1. 
Seksyen $52(1)^{10}$ telah jelas memperuntukkan bahawa memberi hak kepada seorang perempuan untuk membubarkan perkahwinannya secara fasakh atas satu atau lebih alasan. Makna harfiahnya dapat difahami dengan mudah, iaitu perkahwinan boleh difasakh dengan satu atau lebih alasan tanpa mengambil kira berapa banyak alasan yang dikemukakan untuk membubarkan perkahwinan. Ini adalah kerana semua alasan fasakh yang diperuntukkan di bawah seksyen tersebut adalah untuk membebaskan seseorang perempuan daripada perkahwinan yang memudaratkannya dari segi fizikal, mental, agama, seksual dan kesihatan. Sebagai contoh, jika seorang isteri telah mengemukakan beberapa alasan di dalam tuntutan fasakh dan beliau hanya berjaya membuktikan satu sahaja alasan, maka perkahwinan tersebut boleh dibubarkan tanpa mengambil kira alasan-alasan yang lain.

Y.A.A Hakim juga mengulas sepatutnya tafsiran tersebut tidak patut lagi berlaku di mana sebelum ini iaitu pada tahun 1990 telah ada satu kes di peringkat Mahkamah Rayuan Syariah Negeri Selangor dalam kes Hairun Mohd Sharif lwn. Omar Mohd Nor ${ }^{11}$ telah memutuskan untuk membenarkan rayuan perayu untuk membubarkan perkahwinannya atas alasan suami lazim menyakiti atau menjadikan kehidupannya menderita disebabkan kelakuan aniaya. Keputusan ini dicapai apabila Mahkamah Rayuan Syariah mendapati pihak perayu (isteri) telah berjaya membuktikan alasan tersebut. Dalam kes ini, Mahkamah Rendah Syariah sebelum ini telah menolak tuntutan fasakh perayu kerana gagal membuktikan ketiga-tiga alasan fasakh iaitu suami cuai memberikan nafkah selama tiga (3) bulan, suami hidup berperangai keji menurut hukum Syarak dan suami lazim menyakiti atau menjadikan kehidupannya menderita disebabkan kelakuan aniayanya. Oleh yang demikian, Mahkamah Rayuan Syariah telah meluluskan tuntutan fasakh pihak perayu walaupun perayu hanya berjaya membuktikan satu alasan daripada alasan-alasan yang lain.

Kes tersebut menunjukkan bahawa sekiranya pihak isteri membuat permohonan agar mahkamah membubarkan perkahwinannya, memadai hanya satu alasan fasakh sahaja yang berjaya dibuktikan oleh pihak isteri walaupun terdapat alasan-alasan yang lain yang tidak berjaya dibuktikan di mahkamah. Hal ini kerana, menurut penulis juga, tujuan utama fasakh itu sendiri adalah untuk mengelakkan para isteri daripada berterusan menderita sama ada dari segi fizikal atau mental.

Malah, berdasarkan kepada kajian yang dibuat oleh Raihanah Haji Abdullah (1997: 51), kes-kes perceraian di Mahkamah Syariah sering berlaku penangguhan disebabkan oleh beban pembuktian (burden of proof) bagi kes

\footnotetext{
10 Akta Undang-undang Keluarga Islam (Wilayah-Wilayah Persekutuan) 1984, Akta 303, seksyen 52 (1)

11 Hairun Mohd Sharif lwn. Omar Mohd Nor [1990] JH 8/2.
} 
ta 'liq dan fasakh adalah berat sehingga ada yang beranggapan bahawa untuk membuktikan suami telah melanggar mana-mana peruntukan yang berkaitan adalah seolah-olah seperti pembuktian dalam kes-kes jenayah.

Mengikut Sheikh Ghazali Haji Abdul Rahman (2005: 1-7), kelewatan pelantikan Hakim Mahkamah Rendah yang baru apabila berlaku pertukaran hakim atau pelantikan hakim baru juga menyebabkan banyak kes-kes tertangguh pendengarannya sehingga menimbulkan rungutan dan kritikan masyarakat Islam yang memerlukan sesuatu perintah yang segera.

Ini menunjukkan bahawa faktor mengenai alasan-alasan fasakh bukanlah menjadi punca kepada kelewatan perbicaraan kes fasakh di Mahkamah Syariah. Malah aduan-aduan yang sering dibangkitkan oleh masyarakat melalui media massa dan pihak-pihak berautoriti mengenai isu-isu kelewatan perbicaraan juga bukan berpunca daripada undang-undang substantif, tetapi sebaliknya proses dan prosedur yang perlu ditempuhi oleh pihak isteri dari awal hingga akhir perbicaraan begitu rumit dan menyulitkan sehingga menyebabkan berlaku penangguhan yang tidak wajar.

Manakala hasil kajian projek IRPA UM yang dijalankan oleh Narizan Abdul Rahman (2005: 1-26), telah mengenalpasti bahawa terdapat permasalahan dalam undang-undang prosedur yang antara lain merangkumi aspek-aspek permasalahan seperti peruntukan tidak lengkap, pertindihan bidangkuasa, penggunaan borang dan peruntukan undang-undang tidak selaras serta tidak jelas dari segi prosedur perbicaraan, saman di luar bidangkuasa serta terdapat juga peruntukan undang-undang tersebut tidak difahami atau diketahui oleh pihak-pihak yang bertikai di mahkamah.

\section{TUNTUTAN FASAKH DARI PERSPEKTIF UNDANG-UNDANG TATACARA MAL}

Selanjutnya, penulis akan menelusuri prosedur dan amalan tuntutan fasakh berdasarkan peruntukan undang-undang tatacara mal kini dengan melihat secara holistik proses yang perlu diikuti berdasarkan peruntukan undangundang tersebut. Walaupun masih terdapat perbezaan peruntukan di antara negeri-negeri di Malaysia selepas penyeragaman peruntukan undang-undang tatacara mal, namun perbezaan tersebut kebanyakannya terdapat pada susunan seksyen dan nama sahaja, tetapi isi kandung serta butiran peruntukan adalah sama.

Sebagai contoh, penulis akan merujuk kepada Enakmen Tatacara Mal Negeri Selangor Tahun 2003 yang memperuntukkan perkara-perkara berikut sebagai asas tindakan prosiding di mahkamah: 


\section{Proses Penyampaian Saman dan Pernyataan Tuntutan}

Proses penyampaian saman dan pernyataan tuntutan hendaklah dimulai oleh pihak menuntut kepada pihak kena tuntut. Kepentingan proses ini amat ketara apabila undang-undang menghendaki saman atau notis berkenaan disampaikan secara ke diri sama ada oleh pihak plaintif/pemohon sendiri ataupun wakilnya sebagaimana seksyen 41 Enakmen Tatacara Mal Mahkamah Syariah Selangor Tahun 2003. ${ }^{12}$

Jika penyampaian ke diri tidak dapat dibuat, maka ianya boleh dibuat secara penyampaian ganti seperti tampalan, pos berdaftar ataupun iklan di dalam akhbar tempatan sepertimana yang diperuntukkan di dalam seksyen 48 Enakmen Tatacara Mal Mahkamah Syariah Negeri Selangor 2003. ${ }^{13}$

12 Seksyen 41 Enakmen Tatacara Mal Mahkamah Syariah Negeri Selangor 2003 menyebut:

(1) Tertakluk kepada Bahagian ini, sesuatu saman atau dokumen lain hendaklah disampaikan ke diri, dan hendaklah dilaksanakan dengan menyerahkan saman atau dokumen lain itu, atau dengan mengemukakannya untuk diperiksa dan menyerahkan satu salinan saman atau dokumen lain itu, kepada orang yang kepadanya saman atau dokumen itu hendak disampaikan.

(2) Bagi maksud subseksyen (1), suatu salinan yang mengandungi meterai mahkamah dan tandatangan Pendaftar hendaklah disifatkan sebagai suatu saman atau dokumen asal.

(3) Penyampaian sesuatu saman atau dokumen lain hendaklah dilaksanakan oleh pegawai mahkamah atau mana-mana orang lain.

13 Seksyen 48, Enakmen Tatacara Mal Mahkamah Syariah Negeri Selangor 2003:

(1) Jika mahkamah berpuas hati bahawa atas apa-apa alasan yang mencukupi saman atau dokumen lain itu tidak dapat disampaikan secara biasa, mahkamah boleh memerintahkan supaya saman atau dokumen lain itu disampaikan dengan cara menampalkan suatu salinannya dipapan kenyataan mahkamah dan juga di suatu tempat yang mudah dilihat di bangunan tempat orang yang kepadanya saman atau dokumen itu hendak disampaikan terakhir diketahui tinggal, atau mengikut apa-apa cara lain yang difikirkan patut oleh mahkamah.

(2) mahkamah boleh juga, dalam mana-mana hal yang termasuk dalam subseksyen

(1), membuat perintah supaya penyampaian dibuat melalui iklan dalam manamana akhbar tempatan sebagaimana yang difikirkan patut oleh mahkamah.

(3) Penyampaian ganti hendaklah mempunyai kesan yang sama seperti penyampaian ke diri.

(4) Dalam hal penyampaian ganti, mahkamah hendaklah, jika perlu, menetapkan masa bagi pihak yang berkenaan itu hadir di mahkamah.

(5) Tiada perintah bagi penyampaian ganti boleh dibuat berkenaan dengan:

(a) sesuatu sepina; atau

(b) apa-apa dokumen yang memulakan prosiding bagi penangkapan atau 
Begitu juga bagi kes orang yang tidak berupaya menerima saman, maka saman tersebut boleh diserahkan kepada penjaga ad litemnya. Bagi banduan, saman tersebut boleh diserahkan kepada pegawai yang menjaga penjara, manakala bagi angkatan tentera, saman boleh disampaikan kepada pegawai pemerintah, sebagaimana yang diperuntukkan di dalam seksyen 47 Enakmen Tatacara Mal Mahkamah Syariah Negeri Selangor Tahun 2003. ${ }^{14}$

Oleh yang demikian, pihak defendan tidak boleh mengelakkan dirinya daripada menerima saman kerana proses penyampaian hanya perlu dilaksanakan sebagai syarat bagi membolehkan kes diteruskan. Ini bermaksud, sebarang keingkaran untuk menerima saman atau cubaan mengelakkan diri dari menerima saman tidak akan memberi kesan kepada sesuatu kes itu untuk didengar dan diputuskan oleh Hakim Bicara. Keputusan ini dapat dilihat dalam kes Rosnani Hassan Abdullah lwn. San Ahmed Abu Zarin ${ }^{15}$ di hadapan Y.A Hakim Haji Payate Deman pada 23 Januari 1989. Di dalam kes ini plaintif telah membuat tuntutan fasakh oleh kerana suaminya telah meninggalkannya dan tidak memberikan apa-apa nafkah selama tempoh setahun. Pihak defendan tidak hadir walaupun saman telah dikeluarkan dan disempurnakan. Perbicaraan kes ini ditangguhkan kepada tarikh lain disebabkan ketidakhadiran defendan.

Perbicaraan disambung semula pada 23 Januari 1989, jam 10.00 pagi. Pada hari berkenaan, plaintif ada hadir, tetapi defendan tidak juga hadir tanpa sebarang alasan, walaupun surat panggilan telah dihantar pada 09 Januari

pengkomitan mana-mana orang.

(6) Apa-apa permohonan bagi perintah di bawah seksyen ini hendaklah disokong dengan afidavit yang menyatakan fakta yang menjadi asas permohonan itu.

14 Seksyen 47, Enakmen Tatacara Mal Mahkamah Syariah Negeri Selangor 2003 menyebut:

(1) Penyampaian kepada seseorang orang tak berkeupayaan hendaklah dibuat kepada oenjaga ad litemnya, jika ada.

(2) Walau apa pun subseksyen (1), mahkamah boleh, atas permohonan, memerinthakan supaya penyampaian kepada seseorang orangtak berkeupayaan dibuat kepada mana-mana orang lain.

(3) Penyampaian kepada seseorang di dalam penjara hendaklah dibuat kepada pegawai yang menjaga penjara itu, yang hendaklah menyebabkan saman atau dokumen lain itu diberikan kepada orang itu.

(4) Penyampaian kepada mana-mana anggota Angkatan Tentera hendaklah dibuat kepada pegawai pemerintah atau adjutant unitnya, yang hendaklah menyebabkan saman atau dokumen lain itu diberikan kepada anggota itu.

15 Rosnani Hassan Abdullah lwn. San Ahmed Abu Zarin [1989] Kes Mal Bil: 85/88, Mahkamah Tinggi Syariah Negeri Melaka. 
1989 dan surat tersebut tidak dikembalikan semula kepada mahkamah. Oleh itu, mahkamah menganggap defendan telah menerima surat tersebut. Setelah mahkamah mendengar keterangan plaintif dan disokong oleh dua orang saksi, mahkamah mensabitkan tuntutan fasakh plaintif dengan defendan. ${ }^{16}$

Seterusnya, penulis juga merujuk kes Radzi Abdullah lwn. Nursuyaireen Radzi dan Seorang Yang Lain ${ }^{17}$ di mana kes ini merupakan rayuan oleh pihak perayu sama ada keputusan yang dibuat oleh Mahkamah Bicara adalah sah sekiranya saman tidak disampaikan secara sempurna kepada pihak defendan (perayu dalam kes ini). Y.A.A Hakim telah mengulas bahawa Y.A Hakim Bicara dalam alasan penghakimannya telah mengakui bahawa afidavit tanpa serah jelas menyatakan notis sulh gagal disampaikan kepada pihak perayu. Tindakan Y.A Hakim Bicara yang meneruskan perbicaraan sedangkan telah jelas bahawa penyampaian saman belum disempurnakan ke atas perayu adalah sesuatu yang luar biasa. Ini adalah kerana, prosedur selepas sulh gagal disempurnakan adalah prosedur penyampaian saman, tetapi ianya telah tidak dilaksanakan. Y.A Hakim Bicara menerima kenyataan peguam syarie responden bahawa saman telah disempurnakan kepada perayu tanpa meminta dibuktikan melalui afidavit penyampaian.

Y.A.A Hakim mengulas bahawa tindakan Y.A Hakim Bicara tersebut adalah menyalahi peruntukan seksyen 121 (1) (b) ${ }^{18}$ yang memperuntukkan seperti berikut:

"Seksyen 121. Ketidakhadiran pihak-pihak.

Jika, apabila mana-mana tindakan dipanggil untuk pendengaran:

defendan tidak hadir, mahkamah boleh, tertakluk kepada bukti penyampaian wajar, mendengar dan memutuskan tindakan itu tanpa kehadirannya"

Maksud "penyampaian wajar" adalah sama ada secara penyampaian ke diri atau secara penyampaian ganti sebagaimana yang diperuntukkan dalam seksyen 41 dan seksyen $48^{19}$ Akta 585. Menghadirkan pihak defendan adalah menjadi suatu syarat dalam sesuatu perbicaraan mengikut hukum Syarak. Y.A.A Hakim telah merujuk kepada tulisan 'Abd al-Karīm Zaydān dalam

16 Bahagian Hal Ehwal Islam, Jabatan Perdana Menteri: Kuala Lumpur [1990] JH 7/1, 102-104.

17 Radzi Abdullah lwn. Nursyaireen Radzi dan Seorang Yang Lain [2013] JH 36/1.

18 Akta Tatacara Mal Mahkamah Syariah (Wilayah-wilayah Persekutuan) 1998 (Akta 585).

19 Akta Tatacara Mal Mahkamah Syariah (Wilayah-Wilayah Persekutuan) 1998 (Akta 585). 
bukunya Niẓām al-Qaḍ̄' fì al-Syarī'ah al-Islāmiyyah, halaman 144 yang menyatakan sebagaimana berikut:

"Sebelum Hakim menjalankan perbicaraan, mendengar sebarang tuntutan dan keterangan pihak Yang menuntut, penafian atau iqrar pihak Yang kena tuntut, maka Hakim hendaklah terlebih dahulu menghadirkan pihak Yang kena tuntut sekiranya dia tidak hadir dengan sendiri..."

Manakala penyampaian saman, adalah suatu kaedah yang dipilih oleh undang-undang sebagai satu cara untuk menghadirkan pihak yang kena tuntut. Oleh itu, sama ada melalui penyampaian secara ke diri atau secara ganti, ianya adalah sesuatu yang mesti dilakukan. Kegagalan untuk mematuhi seksyen 121 (1) (b) yang dibaca bersama seksyen 41 dan subseksyen 48 91) 92) ${ }^{20}$ ini boleh menyebabkan prosiding perbicaraan yang dijalankan dikira sebagai tidak sah dan terbatal.

Dalam kes tersebut, walaupun Y.A Hakim Mahkamah Bicara sebelum ini merujuk kepada peruntukan yang sama iaitu seksyen $5^{21}$ mengenai ketidakpatuhan mana-mana prosedur tidak membatalkan prosiding, tetapi Y.A Hakim Bicara gagal mempertimbangkan soal keperluan penyampaian saman sama ada ia menjadi syarat sah prosiding atau sebaliknya. Ini kerana, hanya dengan penyampaian saman, mahkamah boleh mendengar dari kedua-dua belah pihak sebelum sesuatu hukuman/keputusan dibuat. Ianya tidak boleh dilakukan kecuali setelah saman sempurna disampaikan. Sama ada defendan hadir atau tidak selepas itu, ianya suatu persoalan lain. Justeru, Y.A.A Hakim Mahkamah Rayuan telah membuat keputusan untuk menerima rayuan perayu dan penghakiman Y.A Hakim Bicara adalah tidak sah dan terbatal apabila penyampaian saman tidak disempurnakan ke atas pihak perayu sebelum perbicaraan dijalankan.

Penulis juga merujuk kes Hafizah Indra Abdullah lwn. Jamaluddin Eusoff ${ }^{2}$ dalam kes tersebut, pada peringkat awal perbicaraan defendan hadir dan hanya memfailkan pembelaan sahaja. Mahkamah telah mengarahkan agar kes tersebut dibicarakan atas alasan semua bukti penyampaian saman dan kehadiran defendan ke mahkamah pada awalnya telah menyakinkan mahkamah bahawa defendan mengetahui hal berkaitan kes ini. Mahkamah telah beberapa

\footnotetext{
20 Akta Tatacara Mal Mahkamah Syariah (Wilayah-Wilayah Persekutuan) 1998 (Akta 585).

21 Akta Tatacara Mal Mahkamah Syariah (Wilayah-Wilayah Persekutuan) 1998 (Akta 585).

22 Hafizah Indra Abdullah lwn. Jamaluddin Eusoff [2006] 22/1.
} 
kali menghantar notis bicara bertujuan memaklumkan kepada defendan tetapi masih gagal hadir pada tarikh perbicaraan yang ditetapkan oleh mahkamah ini.

Peguam plaintif juga memohon kepada mahkamah supaya meneruskan kes tanpa kehadiran defendan kerana semua proses saman telah disempurnakan dan defendan telah maklum mengenai tarikh-tarikh perbicaraan kerana notis tangguhan dan makluman bicara telah dihantar kepada defendan. Mahkamah juga bersetuju bahawa mahkamah mempunyai bidangkuasa dan budibicara untuk meneruskan kes walaupun defendan gagal hadir. Ianya adalah berdasarkan seksyen 121 (1) (b) Enakmen Tatacara Mal Mahkamah Syariah (Negeri Pulau Pinang) 1999. Seksyen tersebut juga jelas memberi kuasa budi bicara untuk mahkamah memutuskan bahawa kes boleh diteruskan tanpa kehadiran defendan atas dasar beliau tidak membantah mengenai tuntutan kes ini. Mahkamah juga telah memberi peluang untuk defendan membuat Pembelaan dan defendan gagal untuk memberikan keterangan dan mahkamah ini beranggapan bahawa beliau bersetuju atas tuntutan plaintif kerana diam beliau itu melambangkan persetujuan sepertimana rujukan dalam kitab Ahkam al-'Adliyyah Perkara 67 yang bermaksud:

\section{"diam defendan itu bukti beliau bersetuju di atas tuntutan tersebut..."}

Mahkamah juga merujuk kepada satu kaedah fiqh yang bermaksud sebagaimana berikut:

$$
\begin{aligned}
& \text { "...yang terkenal di dalam 'urf seperti terkenal di dalam } \\
& \text { syarat..." }
\end{aligned}
$$

Berpandukan rujukan-rujukan tersebut, mahkamah bersetuju bahawa mahkamah ini berbidangkuasa memutuskan kes tanpa kehadiran defendan dan mahkamah beranggapan bahawa ketidakhadiran itu seolah-olah beliau bersetuju tentang tuntutan ini sepertimana nas hukum Syarak dalam kitab yang disebutkan di atas. Defendan sepatutnya hadir dan memberi keterangan supaya mahkamah dapat menilai tuntutan yang dibuat, tetapi kegagalan itu menyulitkan beliau jika keputusan yang akan dibuat ini tidak dapat dinilai dengan tepat oleh mahkamah.

Daripada kajian yang dibuat oleh penulis, didapati bahawa mahkamahmahkamah Syariah seluruh negara telah menyeragamkan pemakaian mengenai kaedah penyampaian saman kepada pihak-pihak yang terlibat. Perkara ini merangkumi alamat penyampaian, cara penyampaian dan kaedah menangani masalah ketidakterimaan, penyampaian ganti sama ada penyampaian dalam bidangkuasa mahupun di luar bidangkuasa mahkamah. 
Namun begitu, isu penyampaian saman dan dokumen ini perlu diperhalusi semula bagi menangani masalah kegagalan penyampaian saman yang memerlukan suatu permohonan baru difailkan bagi kebenaran penyampaian ganti di hadapan Hakim Bicara. Ini kerana proses tersebut akan mengambil masa yang panjang dan boleh melewatkan perjalanan kes. Oleh yang demikian, penulis mencadangkan supaya kebenaran untuk penyampaian tersebut boleh didengar secara perakuan segera di hadapan pendaftar sebelum tarikh sebutan kali pertama bagi memastikan proses penyampaian telah disempurnakan.

\section{Mahkamah Yang Berbidangkuasa Mendengar Kes}

Sebagaimana yang disebut sebelum ini, proses pemfailan kes fasakh adalah berdasarkan bidangkuasa yang diperuntukan oleh undang-undang setiap negeri. Sebagaimana Arahan Amalan Jabatan Kehakiman Syariah Malaysia (JKSM), setiap kes yang difailkan akan diberikan nombor pendaftaran dengan kod yang berbeza. Bagi kes fasakh kod kes adalah 014 dan ianya telah diseragamkan pemakaiannya di seluruh negara. ${ }^{23}$

Perkara yang paling penting perlu dikenalpasti sebelum sesuatu pemfailan dibenarkan atau diterima oleh mahkamah ialah mengenai bukti pemastautinan. Ini kerana ianya menjadi punca kuasa seseorang Hakim untuk mendengar dan memutuskan kes yang difailkan di mahkamah berkenaan. ${ }^{24}$

Kepentingan kepada pematuhan seksyen berkenaan dapat dilihat kepada keputusan dan arahan mahkamah terhadap kes-kes yang telah diputuskan. Sebagai contohnya, di dalam kes Kelthom lwn. Ismail, ${ }^{25}$ plaintif menuntut fasakh daripada suaminya yang tidak bersamanya dan tidak menunaikan nafkah zahir dan batin kepadanya melebihi satu tahun. Suami tidak hadir kerana sukar untuk dicari. Bagi maksud menentukan tuntutan ini, mahkamah terlebih dahulu melihat kepada peruntukan undang-undang bagi memastikan bidangkuasanya. Seksyen 42 Enakmen Undang-undang Pentadbiran Keluarga Islam 1985 memperuntukkan:

23 Arahan Amalan JKSM No.1 Tahun 2000.

24 Seksyen 4 Enakmen Undang-undang Keluarga Islam Negeri Selangor Tahun 2003 memperuntukkan: "Kecuali sebagaimana yang diperuntukkan dengan nyata selainnya, Enakmen ini terpakai bagi semua orang Islam yang tinggal dalam Negeri Selangor dan bagi semua orang Islam yang bermastautin dalam Negeri Selangor tetapi tinggal di luar Negeri itu.."

25 Kelthom lwn. Ismail [1995] Permohonan No: MTSTR 41/010/1/95 di hadapan Yang Arif Hakim Haji Ismail Yahya pada 19 April 1995 di Mahkamah Tinggi Syariah Kuala Terengganu. 
"Kecuali sebagaimana diperuntukkan selainnya dengan nyata, tiada apa-apa jua dalam Enakmen ini membolehkan mahkamah membuat sesuatu perintah perceraian atau perintah mengenai perceraian atau membenarkan seseorang suami melafazkan talaq kecuali;

jika perkahwinan ini telah dilangsungkan mengikut hukum Syarak; dan

jika pemastautinan adalah satu pihak kepada perkahwinan pada masa permohonan itu diserahkan di Terengganu."

Mengenai pemastautinan, mahkamah berpuashati bahawa kedua-dua mereka adalah bermastautin di Terengganu semasa tuntutan atau permohonan ini dibuat. Oleh itu, mahkamah membenarkan tuntutan plaintif bagi memohon untuk fasakh nikahnya dengan defendan (Ibid: 50).

Manakala contoh kes berkenaan dengan bidangkuasa mahkamah untuk mendengar dan memutuskan kes fasakh adalah sebagaimana kes Joan Mary Sulaiman lwn. Sulaiman Haji Musa. ${ }^{26}$ Dalam kes ini, pihak-pihak telah berkahwin di Sydney, Australia pada 29 November 1961. Selepas akad nikah, pasangan ini masih tinggal di Australia hampir setahun lebih. Setelah dikurniakan seorang anak, defendan telah menghantar plaintif dan anak tersebut ke Malaysia dan menempatkan plaintif bersama anaknya di Pasir Mas, Kelantan Darul Naim dan defendan masih berada di Australia untuk meneruskan pengajian. Setelah defendan selesai pengajiannya dalam tahun 1963, defendan telah pulang ke Malaysia dan tinggal bersama plaintif serta keluarga defendan. Defendan telah mendapat pekerjaan di Kuala Lumpur dan berkahwin dengan isteri keduanya serta tinggal bersama di rumah kelamin yang beralamat di No. 621, Desa Damansara Jalan 99, Jalan Setiakasih, Damansara Heights, Kuala Lumpur. Manakala plaintif selaku isteri pertama ditempatkan oleh defendan tinggal di rumah yang beralamat di No. 2032, Taman Sari, Jalan Hospital, Kota Bharu, Kelantan yang bertugas sebagai Penyelia Jururawat Perancang Keluarga, Lembaga Penduduk dan Pembangunan Keluarga Negara Malaysia.

Sebelum kes ini didengar di atas tuntutan yang dikemukakan oleh peguam plaintif, pihak defendan diwakili oleh peguam syarienya mempertikaikan tentang bidangkuasa mahkamah ini, oleh kerana plaintif tinggal di Kota Bharu, Kelantan Darul Naim dan sebenarnya bukanlah tinggal di alamat No. 621, Desa Damansara Jalan 99, Jalan Setiakasih, Damansara Heights, Kuala Lumpur sebagaimana di alamat dalam permohonan kes yang difailkan. Oleh

26 Joan Mary Sulaiman lwn. Sulaiman Haji Musa [1995] JH 10/1. 
itu, plaintif berhak mengemukakan tuntutannya di Kota Bharu, Kelantan Darul Naim.

Setelah mahkamah mendengar keterangan kedua belah pihak dan rujukan siasatan penghantar saman Mahkamah Syariah Wilayah Persekutuan, mahkamah dapati defendan tinggal di Wilayah Persekutuan di rumah yang beralamat di No. 621, Desa Damansara Jalan 99, Jalan Setiakasih, Damansara Heights, Kuala Lumpur adalah di dalam bidangkuasa Wilayah Persekutuan. Maka, berdasarkan peruntukan seksyen 45(c) ${ }^{27}$ yang menyebut:

"Kecuali sebagaimana diperuntukkan selainnya dengan nyata, tiada apa-apa jua dalam Akta ini membolehkan mahkamah membuat sesuatu perintah perceraian atau perintah mengenai perceraian atau membenarkan seseorang suami melafazkan talaq kecuali:

(a) jika perkahwinan itu telah didaftarkan atau disifatkan sebagai didaftarkan di bawah Akta ini; atau

(b) jika perkahwinan itu telah dilangsungkan mengikut hukum Syarak; dan

jika permastautinan salah satu pihak kepada perkahwinan pada masa permohonan itu diserahkan adalah dalam Wilayah Persekutuan." 28

Dengan peruntukan ini, plaintif berhak mengemukakan tuntutan perceraian secara fasakh di mahkamah ini dengan alasan pihak defendan atau suami kepada plaintif tinggal di Wilayah Persekutuan. Oleh yang demikian, tidak sepatutnya dibenarkan mana-mana pihak membangkitkan bantahan pada mana-mana peringkat prosiding mengenai isu pemastautinan jika salah satu pihak bermastautin di bawah bidangkuasa mahkamah berkenaan. Jika perkara ini dibenarkan, maka akan menyebabkan kelengahan yang tidak perlu kepada perjalanan kes sehingga menyebabkan kes tersebut lewat diselesaikan.

\section{Proses Perbicaraan Tuntutan Fasakh}

Perbicaraan adalah merupakan proses terpenting dalam sesuatu tuntutan yang tiada penyelesaian secara persetujuan bersama. Bagi kes fasakh, jika persetujuan dicapai sama ada suami isteri setuju bercerai secara baik atau

27 Akta Undang-undang Keluarga Islam (Wilayah-wilayah Persekutuan) 1984 (Akta 303).

28 Sekyen 45, Akta Undang-Undang Keluarga Islam (Wilayah-wilayah Persekutuan) 1984. 
kedua-duanya berbaik semula, kes fasakh tersebut hendaklah ditarik balik dengan kebenaran mahkamah. Ini kerana tuntutan fasakh adalah bertujuan untuk mendapatkan perintah daripada hakim bagi membubarkan perkahwinan yang tidak dipersetujui oleh suami mahupun isteri berdasarkan alasan-alasan yang memuaskan hati mahkamah dalam keadaan salah satu pihak tidak bersetuju dengan tuntutan pihak yang satu lagi.

Di Malaysia, prosedur pendengaran kes fasakh adalah sama dengan keskes Mal yang lain di mana Enakmen Tatacara Mal memperuntukkan bahawa semua prosiding yang dimulakan dengan saman hendaklah didengar dan diputuskan di dalam mahkamah terbuka. Manakala pihak-pihak pula boleh hadir sendiri atau melalui peguam syarienya. Kehadiran ke mahkamah adalah wajib dan sekiranya mana-mana pihak gagal hadir ke mahkamah sewaktu pendengaran kes, maka ianya akan mengundang risiko sama ada kes tersebut dibuang jika plaintif yang gagal hadir atau kes akan diputuskan secara sebelah pihak jika defendan gagal hadir tanpa alasan yang munasabah setelah saman telah disampaikan dengan sempurna.

Penulis juga merujuk kes Siti Hasnah Jantan lwn. Saharum Shariffer di mana dalam kes tersebut, mahkamah memerintahkan plaintif untuk bersumpah istizhar terlebih dahulu sebelum keputusan dibuat oleh mahkamah sebagai menguatkan dakwaannya di mahkamah. Ini kerana, perbicaraan kes tersebut adalah dikategorikan sebagai keterangan sebelah pihak iaitu keterangan plaintif dan saksi-saksinya sahaja tanpa kehadiran defendan. Justeru, mahkamah telah memerintahkan plaintif bersumpah dengan yamin istizhar bagi menguatkan dakwaan kesnya.

Ianya adalah bertepatan dengan seksyen 121 Enakmen Tatacara Mal Mahkamah Syariah (Negeri Selangor) 2003 yang telah memperuntukkan mengenai ketidakhadiran pihak-pihak sebagaimana berikut:

"Seksyen 121. Ketakhadiran pihak-pihak

(1) Jika, apabila mana-mana tindakan dipanggil untuk pendengaran:

Tiada satu pihak pun hadir, mahkamah boleh membuang tindakan itu;

Defendan tidak hadir, mahkamah boleh, tertakluk kepada bukti penyampaian wajar, mendengar dan memutuskan tindakan itu tanpa kehadirannya; atau

29 Siti Hasnah Jantan lwn. Saharum Shariff [2013] 1 CLJ (Sya), 189-193. 
Plaintif tidak hadir, mahkamah boleh membuang tindakan itu dan mendengar memutuskan apa-apa tuntutan balas.

(2) Mahkamah hendaklah, sebelum membuat apa-apa penghakiman mengenai tuntutan plaintif di bawah perenggan (1)(b) atau tuntutan balas defendan di bawah perenggan (1)(c), mengarahkan plaintif atau defendan, mengikut mana-mana Yang berkenaan, mengangkat sumpah istizhar.

(3) Jika terdapat lebih daripada seorang plaintif atau defendan dan hanya seorang sahaja daripada mereka Yang hadir, mahkamah boleh mendengar tindakan itu terhadap pihak Yang hadir itu dan memutuskan tindakan itu terhadap pihak-pihak yang tidak hadir mengikut subseksyen (1) atau (2).

(4) Mahkamah boleh mengikut budi bicaranya dalam mana-mana hal yang dinyatakan dalam subseksyen (1) atau (3) memerintahkan penangguhan."

Berdasarkan kes tersebut, sekiranya dilihat kepada amalan dan aplikasi di Mahkamah Syariah, kes-kes yang dibicarakan yang hanya melibatkan kehadiran sebelah pihak, sebelum mahkamah membuat sesuatu keputusan, mahkamah akan memerintahkan pihak yang menuntut atau membuat dakwaan untuk melaksanakan sumpah istizhar bagi mengukuh dan menguatkan dakwaannya di samping sekiranya terdapat keterangan-saksi-saksi yang lain. Sumpah tersebut adalah untuk memastikan keadilan diberikan dengan sewajarnya bagi kedua-dua belah pihak.

Seterusnya, mahkamah merujuk kes Noor Liza Haji A. Latif lwn. Muhammad Asri Ismail, ${ }^{30}$ di mana YA Hakim Tuan Othman Ibrahim, Hakim Mahkamah Tinggi Syariah Pulau Pinang telah membuat keputusan bahawa tuntutan plaintif dalam kes tersebut diteruskan untuk perbicaraan setelah mahkamah dapati defendan gagal hadir ke mahkamah dan hanya dua kali hadir tanpa pembelaan difailkan ke mahkamah. Mahkamah berpendapat kes wajar diteruskan kerana mahkamah berpendapat segala proses undang-undang telah pun disempurnakan menurut peruntukan Undang-undang seksyen 121 (1) (b) Enakmen Tatacara Mal Mahkamah Syariah (Negeri Pulau Pinang) 2003 sebagaimana berikut:-

"Seksyen 121. Ketakhadiran pihak-pihak

(1) Jika, apabila mana-mana tindakan dipanggil untuk pendengaran:

30 Noor Liza Haji Latif lwn. Muhammad Asri Ismail [2006] JH 22/2. 
a) Tiada satu pihak pun hadir, mahkamah boleh membuang tindakan itu;

b) Defendan tidak hadir, mahkamah boleh, tertakluk kepada bukti penyampaian wajar, mendengar dan memutuskan tindakan itu tanpa kehadirannya; atau

c) Plaintif tidak hadir, mahkamah boleh membuang tindakan itu dan mendengar memutuskan apa-apa tuntutan balas.

(2) Mahkamah hendaklah, sebelum membuat apa-apa penghakiman mengenai tuntutan plaintif di bawah perenggan (1)(b) atau tuntutan balas defendan di bawah perenggan (1)(c), mengarahkan plaintif atau defendan, mengikut mana-mana yang berkenaan, mengangkat sumpah istizhar.

(3) Jika terdapat lebih daripada seorang plaintif atau defendan dan hanya seorang sahaja daripada mereka yang hadir, mahkamah boleh mendengar tindakan itu terhadap pihak yang hadir itu dan memutuskan tindakan itu terhadap pihak-pihak yang tidak hadir mengikut subseksyen (1) atau (2).

(4) Mahkamah boleh mengikut budi bicaranya dalam manamana hal yang dinyatakan dalam subseksyen (1) atau (3) memerintahkan penangguhan."

Dalam hal ini seksyen 121, Enakmen Tatacara Mal Mahkamah Syariah Negeri Selangor Tahun 2003 memperuntukkan apabila mana-mana tindakan dipanggil untuk pendengaran dan tiada satu pihak pun hadir, maka mahkamah boleh membuang tindakan itu. Jika defendan tidak hadir, mahkamah boleh, tertakluk kepada bukti penyampaian wajar, mendengar dan memutuskan tindakan itu tanpa kehadirannya. Manakala dalam situasi di mana plaintif tidak hadir, maka mahkamah boleh membuang tindakan itu dan memutuskan apaapa tuntutan balas dengan mengarahkan plaintif ataupun defendan, mengikut mana-mana yang berkenaan, mengangkat sumpah istizhar.

Jika diteliti kepada peruntukan-peruntukan di atas, proses dan prosedur perbicaraan sebagaimana yang ditetapkan oleh undang-undang adalah untuk mempercepatkan proses perbicaraan kes. Pihak yang menuntut diberikan hak untuk meneruskan perbicaraan jika sekiranya pihak yang satu lagi sengaja tidak menghadirkan diri ke mahkamah atau memohon penangguhan tanpa sebab yang munasabah. Begitu juga pihak yang kena tuntut akan mendapat keadilan bagi menutup kes ke atasnya jika pihak yang menuntut tidak hadir sewaktu perbicaraan ditetapkan tanpa sebab-sebab yang munasabah. 
Proses memberi keterangan amat penting untuk mengeluarkan keseluruhan pernyataan mahupun pembelaan berserta dengan pembuktian di hadapan Hakim Bicara. Dalam situasi di mana semua pihak hadir, suatu perbicaraan penuh akan dijalankan di mana plaintif hendaklah memulakan dengan membuka kesnya dan memberikan keterangan sebagaimana peruntukan seksyen 126 Enakmen Tatacara Mal Mahkamah Syariah Selangor Tahun 2003. ${ }^{31}$

31 Seksyen 126, Enakmen Tatacara Mal Mahkamah Syariah Negeri Selangor Tahun 2003 menyebut:-

(1) Tertakluk kepada subseksyen (2)-

(a) plaintif hendaklah memulakan dengan membuka kesnya; dan

(b) Setiap pihak boleh, sebelum mengemukakan apa-apa keterangan, membuka kesnya.

(2) Hakim yang di hadapannya suatu tindakan didengar boleh memberi arahan tentang pihak yang akan memulakan dan susunan ucapan pada perbicaraan itu, dan tertakluk kepada apa-apa arahan sedemikian, pihak yang akan memulakan hendaklah mempunyai hak memulakan penggulungan kesnya.

(3) Apabila plaintif telah mengemukakan semua keterangan bagi kesnya, Hakim hendaklah memanggil defendan untuk mengemukakan keterangan bagi menjawab tuntutan plaintif, dan dalam hal sedemikian defendan hendaklah diberi pilihan sama ada hendak mengemukakan keterangan atau mengemukakan hujah bahawa tiada kes perlu dijawab.

(4) Jika defendan memilih untuk mengemukakan keterangan, Hakim hendaklah merekodkan keterangan yang dikemukakan sedemikian, dan setelah defendan memberikan semua keterangan bagi pihaknya, Hakim hendaklah meminta defendan membuat penghujahan untuk menutup kesnya.

(5) Apabila defendan telah menutup kesnya, Hakim hendaklah meminta plaintif mengemukakan hujahnya untuk menjawab hujah defendan dan untuk menutup kesnya.

(6) Walau apa pun apa-apa jua dalam seksyen ini tetapi tertakluk kepada subseksyen (7) dan (8), Hakim boleh memerintahkan mana-mana pihak supaya mengemukakan hujah bertulis mengikut apaapa susunan dan dalam apa-apa tempoh sebagaimana yang diarahkannya.

(7) Jika defendan memilih untuk tidak mengemukakan apa-apa keterangan tetapi memilih untuk mengemukakan hujah bahawa tiada kes untuk dijawab, Hakim hendaklah-

(a) merekodkan penghujahan defendan; dan

(b) mengarahkan defendan mengangkat sumpah menafikan tuntutan plaintif, dan jika defendan enggan mengangkat sumpah sedemikian, Hakim hendaklah, tertakluk kepada subseksyen (8), membuang kes defendan dan membenarkan tuntutan plaintif.

(8) Sebelum mahkamah membenarkan tuntutan plaintif di bawah subseksyen (7), mahkamah hendaklah-

(a) mendengar dan merekodkan penghujahan plaintif dalam menutup kesnya; dan 
Dari segi amalan, apabila plaintif selesai memberikan keterangannya, hakim hendaklah memanggil defendan untuk mengemukakan keterangan bagi menjawab tuntutan plaintif. Keseluruhan keterangan pihak-pihak akan direkodkan oleh mahkamah. Setelah keterangan selesai, maka pihak-pihak hendaklah memasukkan penghujahan menutup kes tersebut berdasarkan kepada arahan mahkamah. Selagimana prosiding kes belum selesai, mahkamah boleh memanggil mana-mana pihak untuk mengemukakan keterangan dan boleh membuat pemeriksaan semula pada semua bahan-bahan bukti yang dikemukakan dalam perbicaraan yang lalu.

Ini kerana proses pembuktian merupakan suatu proses yang amat penting dan perlu bagi memastikan sesuatu dakwaan (fakta persoalan) yang dikemukakan itu benar atau sebaliknya. Pembuktian yang kuat adalah pembuktian yang mencapai tahap keyakinan yang tinggi seperti syahadah (penyaksian) dan iqrar (pengakuan) oleh pihak yang didakwa. Menurut Stephen J. (1886), peraturan mengenai keterangan adalah melibatkan 2 unsur/elemen yang penting iaitu bukti atau fakta yang relevan dan juga pembuktian.

Selain itu, berkaitan dengan isu prosedur sesuatu tuntutan di mahkamah, penulis merujuk kes Ahmad Redzuan Mohd Hanapiah lwn. Jane Betty Tasmini (a) NorAinah Abdullah, ${ }^{32}$ di mana dalam kes tersebut, mahkamah telah menolak rayuan yang dibuat oleh pihak perayu dalam kes tuntutan hadānah dan mengekalkan hak jagaan anak diberikan kepada pihak responden. Dalam kes tersebut, pihak responden sebelum ini telah membuat tuntutan hak penjagaan ke atas empat orang anak di Mahkamah Tinggi Syariah Kuala Lumpur di mana saman dan penyata tuntutan telah diserahkan secara kediri kepada pihak perayu.

Pada sebutan kali pertama pihak perayu tidak hadir tanpa makluman dan mahkamah telah mengeluarkan notis amaran dan peringatan kepada pihak perayu. Manakala, pada sebutan kali kedua, perayu masih tidak hadir tetapi memberikan notis bahawa beliau tidak dapat hadir kerana diarahkan oleh majikannya untuk menjalani kursus. Oleh itu, mahkamah telah menangguhkan kes tersebut dan memberikan notis kepada pihak perayu untuk hadir dan memfailkan pembelaan. Pada sebutan kali ketiga perayu hadir tetapi mahkamah telah dimaklumkan oleh peguam responden bahawa kursus yang dianjurkan oleh pihak perayu telah dibatalkan, namun pihak perayu masih

(b) mengarahkan plaintif mengangkat sumpah mengakui kebenaran tuntutannya, dan jika plaintif enggan mengangkat sumpah sedemikian, mahkamah hendaklah membuang kesnya.

32.Ahmad Redzuan Mohd Hanapiah lwn.Jane Betty Tasmini@NorAinah Abdullah [2014] JH 38/1, 44-46. 
tidak hadir pada prosiding yang lalu. Y.A. Hakim telah menegur sikap perayu kerana masih belum memfailkan pembelaannya. Oleh itu, Y.A. Hakim telah memerintahkan perayu memfailkan pembelaannya dalam tempoh empat belas (14) hari.

Pada sebutan kali keempat, selepas pembelaan diserahkan kepada pihak responden oleh pihak perayu, peguam pihak responden telah mempertikaikan pembelaan pihak perayu kerana dibuat dalam bentuk Afidavit Jawapan, sedangkan sepatutnya pihak perayu memfailkan penyata Pembelaan. Kerana itu Y.A. Hakim telah memerintahkan pihak perayu meminda pembelaannya kepada penyata Pembelaan dalam tempoh dua (2) hari. Pada sebutan kali kelima, pihak perayu masih tidak hadir dan tidak menghantar apa-apa notis kepada mahkamah. Pihak responden juga memaklumkan mereka tidak menerima apa-apa notis daripada pihak perayu yang memaklumkan tidak dapat hadir tanpa menyatakan sebab ketidakhadiran.

Oleh yang demikian, Y.A. Hakim telah menerima permohonan peguam pihak responden supaya pliding pembelaan pihak perayu ditolak mengikut peruntukan seksyen $5^{33}$ kerana sehingga sebutan kali kelima, pihak perayu masih gagal memfailkan pembelaan mengikut format yang betul. Oleh yang demikian, disebabkan keempat-empat orang anak hadir pada masa tersebut, maka Y.A. Hakim telah menemu bual mereka. Berdasarkan kepada pilihan anak-anak tersebut, maka Y.A. Hakim telah memerintahkan hak jagaan kesemua mereka diberikan kepada pihak responden.

Berdasarkan kes tersebut, penulis ingin menjelaskan bahawa dalam memfailkan tuntutan fasakh di mahkamah, pihak-pihak yang membuat tuntutan hendaklah mengikut prosedur yang telah ditetapkan oleh pihak mahkamah. Di mana selepas pihak plaintif (pihak Yang Menuntut) memfailkan penyata tuntutan, pada kebiasaannya pihak mahkamah akan memerintahkan pihak defendan (Yang Kena Tuntut) memfailkan Pembelaan dalam tempoh empat belas (14) hari dan pembelaan tersebut hendaklah dibuat dalam bentuk penyata dan bukannya afidavit. Hal ini kerana, keterangan dalam bentuk afidavit hanyalah untuk kes yang berbentuk permohonan sahaja bukannya tuntutan.

Melalui peruntukan undang-undang di Malaysia, tanggungjawab pihak yang mendakwa mengemukakan bukti telah dinyatakan dengan jelas di dalam undang-undang keterangan. Sebagai contohnya seksyen 87 (1) dan (2) serta seksyen 88 Enakmen Keterangan Mahkamah Syariah Negeri Selangor Tahun 2003, menyebut bahawa dalam kes Mal, undang-undang prosedur memperuntukkan bahawa keterangan dan pembuktian hendaklah diberikan

33 Akta Tatacara Mal Mahkamah Syariah (Wilayah-wilayah Persekutuan) Akta 585. 
oleh yang mendakwa dan jika pihak yang mendakwa gagal membuktikan keterangannya sedangkan yang didakwa menafikan tuntutan terhadapnya, maka pihak yang didakwa dikehendaki mengangkat sumpah mengikut hukum Syarak. Kesan kepada kesanggupan bersumpah dinyatakan sebagaimana berikut:

1) “(a) Jika defendan mengangkat sumpah di bawah subseksyen (1), tuntutan yang dibuat oleh plaintif hendaklah ditolak.

(b) Jika defendan enggan mengangkat sumpah, maka mahkamah bolehlah meminta plaintif mengangkat sumpah dan dengan sumpah itu tuntutannya hendaklah diterima."

Namun begitu, penulis berpendapat bahawa kaedah perbicaraan kes fasakh ini mengambil masa yang panjang untuk diselesaikan kerana memerlukan keterangan lisan di dalam perbicaraan. Hal ini berikutan butiran di dalam pliding tidak boleh dianggap sebagai keterangan pihak-pihak, tetapi sebaliknya ia hanyalah pernyataan awal mengenai fakta-fakta untuk menyokong dakwaan sahaja. Berdasarkan kepada peruntukan yang sedia ada, proses tersebut akan melalui beberapa peringkat perbicaraan iaitu keterangan utama, soal balas, keterangan semula dan pengemukaan dokumen serta saksi-saksi. Keseluruhan tempoh masa perbicaraan yang lazim diambil adalah antara satu ke dua tahun untuk diselesaikan, berasaskan kepada masa tangguhan antara satu ke dua bulan bagi setiap sesi pendengaran.

Berbanding dengan kaedah notis permohonan dan afidavit, mahkamah pada dasarnya boleh memutuskan kes fasakh berdasarkan kepada proses pendengaran yang ringkas dengan meneliti kepada fakta-fakta dan buktibukti yang telah diangkat sumpah oleh pihak-pihak melalui afidavit masingmasing. Melalui kaedah ini, masa yang diperlukan oleh mahkamah hanyalah empat sesi pendengaran sahaja iaitu sebutan, pengemukaan afidavit jawapan pihak responden, pengemukaan afidavit jawapan balas pihak pemohon dan penghujahan. Dengan demikian, masa perbicaraan kes dapat disingkatkan kepada empat bulan sahaja berasaskan kepada tangguhan dua hingga tiga minggu bagi setiap sesi pendengaran.

\section{Prosedur Rayuan}

Hak untuk merayu wajar diberikan kepada mana-mana pihak yang tidak berpuashati dan terkilan dengan keputusan yang diberikan oleh Hakim Bicara. Hak ini adalah berdasarkan kepada seksyen 139, ETMMSS 2003. Secara praktikalnya, proses rayuan juga akan mengambil masa yang lama dan lebih memeritkan bagi kaum wanita apabila pihak suami memohon penggantungan 
perlaksanaan perintah fasakh. ${ }^{34}$ Berdasarkan kepada Arahan Amalan JKSM No. 1 Tahun 2005 memperuntukkan secara jelas berkenaan penggantungan suatu perlaksanaan perintah sementara menunggu prosiding kes rayuan berlangsung sebagaimana yang menyebut:

"Saya ingin menarik perhatian Y.A.A kepada keputusan Mesyuarat Arahan Amalan mahkamah Syariah seluruh Malaysia Bil. 1 Tahun 2005 pada 10hb.-12hb. April 2005 bersamaan 1hb.3hb. Rabiulawwal $1426 \mathrm{H}$ di Shah Alam, Selangor telah bersetuju dan mengesahkan untuk menerima pakai arahan amalan mengenai perayu membuat rayuan dengan alasan tidak berpuas hati dengan keputusan mahkamah yang dirayu dalam kes Mal, menurut hukum Syarak adalah memadai untuk menggantung pelaksanaan perintah, sementara menunggu keputusan rayuan dan rujukan hendaklah dibuat kepada mana-mana kes yang telah diputuskan oleh mahkamah yang lebih tinggi kecuali dalam kes-kes nafkah, upah menyusu, tempat tinggal, haḍ̄nah dan serah anak yang belum mumayyiz kepada ibu." 35

Peruntukan dan arahan amalan tersebut akan menyebabkan pihak isteri terpaksa menunggu tempoh yang lebih lama sementara perbicaraan rayuan diselesaikan. Namun dari satu sudut yang lain, jika penggantungan ini tidak dibenarkan dan rayuan tersebut memihak kepada pihak suami, maka sekiranya isteri telah berkahwin lain, perkahwinan kedua itu terpaksa dibubarkan. Keadaan ini sudah pasti akan mendatangkan kesulitan yang lebih besar jika isteri telah mengandung sedangkan perkahwinan beliau terpaksa dibubarkan.

Sehubungan dengan itu, proses rayuan perlu dipercepatkan selaras dengan peruntukan masa yang diberikan oleh undang-undang yang sedia ada. Namun begitu, berdasarkan kepada penelitian penulis, peruntukan masa yang munasabah bagi tindakan pihak-pihak melengkapkan dokumen masing-masing telah ada tetapi peruntukan masa untuk pihak mahkamah mengeluarkan catatan perbicaraan dan alasan penghakiman tidak terdapat dalam undang-undang tersebut. Keadaan ini menjadi punca sebenar kepada kelewatan perjalanan kes rayuan disebabkan alasan rayuan dan rekod rayuan tidak dapat disempurnakan dalam tempoh yang munasabah selepas notis rayuan difailkan. Masalah ini

34 Seksyen 144 Enakmen Tatacara Mal Mahkamah Syariah Negeri Selangor Tahun 2003 menyebut: Pemfailan suatu notis rayuan tidaklah berkuat kuasa sebagai penggantungan pelaksanaan, tetapi mahkamah boleh, atas permohonan dan apabila sebab yang mencukupi ditunjukkan, menggantung pelaksanaan atas apaapa terma sebagaimana yang difikirkannya patut.

35 Arahan Amalan JKSM Tahun 2005, No. 1. 
juga timbul ekoran daripada perbicaraan yang terlalu lama di mahkamah asal sehingga melibatkan beberapa orang Hakim Bicara atau Hakim Bicara telah bertukar dan tidak sempat menyediakan alasan penghakiman atau catatan perbicaraannya tidak dapat dibaca oleh pembantu Hakim.

Bagi mengatasi masalah tersebut, pindaan peruntukan Undang-undang Tatacara Mal mengenai tempoh masa bagi pihak Hakim Bicara mengeluarkan alasan penghakiman dan catatan perbicaraan perlu dibuat supaya tiada lagi ruang yang menjadi punca kepada kelewatan proses rayuan.

Selanjutnya, penulis merujuk kes Hamzah Omar lwn. Haslina Halim, ${ }^{36}$ di mana dalam kes ini pihak perayu telah membuat rayuan ke Mahkamah Rayuan Syariah Negeri Perlis selepas Mahkamah Tinggi Syariah menolak permohonannya untuk memfailkan permohonan lanjutan tempoh masa rayuan atas alasan perayu telah gagal mengemukakan alasan khas dalam permohonannya sehingga mengambil masa selama tempoh sepuluh (10) bulan untuk memfailkan permohonan lanjutan tempoh masa rayuan tersebut. Selain itu, pihak perayu dan peguam syarienya juga tidak hadir sewaktu Mahkamah Rendah Syariah memutuskan kes fasakh walaupun notis telah pemberitahuan kes telah dikeluarkan.

Menurut dakwaan pihak perayu, beliau hanya mengetahui mengenai perintah/penghakiman pembubaran perkahwinan (fasakh) selepas pihak responden menyerahkan sekali bersama saman dan penyata tuntutan harta sepencarian, mut' $a$ h dan hutang piutang yang difailkan oleh pihak responden. Menurut alasan pihak perayu juga, beliau berada dalam keadaan serba salah, keliru dan dilema akibat daripada tindakan tidak profesional responden yang memfailkan tindakan tuntutan $m u t$ ' $a$ h, harta sepencarian dan hutang piutang terhadap perayu tanpa terlebih dahulu memaklumkan dan menyerahkan penghakiman kes fasakh tersebut kepada perayu bagi memberi peluang kepada perayu untuk mengemukakan rayuan jika tidak berpuashati dengan keputusan tersebut.

Dalam penghakiman Y.A.A. Hakim Mahkamah Rayuan Syariah telah mengulas bahawa seksyen yang perlu dirujuk untuk mempertimbangkan alasan-alasan yang diberikan oleh pihak perayu sama ada dikira sebagai alasan-alasan khas selepas terlepas tempoh masa rayuan yang sebenarnya iaitu empat belas (14) hari selepas penghakiman/perintah disampaikan kepadanya adalah dengan merujuk seksyen berikut:

"Seksyen 238. Memanjang atau memendekkan masa

$\overline{36}$ Hamzah Omar lwn. Haslina Halim [2014] JH 38/2. 
mahkamah boleh, atas apa-apa terma yang difikirkannya adil, melalui perintah, melanjutkan atau memendekkan tempoh yang dalamnya seseorang dikehendaki atau dibenarkan oleh Enakmen ini atau oleh mana-mana penghakiman, perintah atau arahan untuk melakukan apa-apa perbuatan dalam mana-mana prosiding."

Walau bagaimanapun, seksyen tersebut tidak memperincikan faktor-faktor yang perlu diberi pertimbangan dalam penggunaan budibicara melanjutkan tempoh. Y.A.A Hakim merujuk kes Aziah Abdul Aziz lwn. Azmi Abdul $A z i z^{37}$ di mana Mahkamah Rayuan Syariah telah menggariskan faktor-faktor pertimbangan sebagaimana berikut:

"Kebenaran untuk melanjutkan masa rayuan adalah merupakan budibicara mahkamah dan mahkamah di dalam melaksanakan budibicaranya akan mengambil kira tempoh kelewatan, alasan kepada kelewatan, kebarangkalian untuk rayuan tersebut dibenarkan dan juga tahap prejudis kepada responden jika permohonan untuk lanjutan dibenarkan. Walaupun begitu, faktor ini hanyalah bentuk panduan bagi melaksanakan budibicara tersebut dan tidak bermaksud menjadi suatu keperluan yang ketat dan mandatori. Ianya juga bukan satu keperluan bahawa semua faktor perlu menyebelahi pihak pemohon di dalam melaksanakan budibicara tersebut."

Kes tersebut mempunyai prinsip yang sama untuk dipakai. Ini kerana, apabila melibatkan soal kelewatan, tidak ada cara untuk perlanjutan tempoh masa dibenarkan melainkan sebab-sebab kelewatan diberikan dan sama ada tahap prejudisnya lebih rendah jika perlanjutan diberikan. Ia adalah suatu ' $u r f$ dan adat kebiasaan bagi perkara yang melibatkan kelewatan.

YA.A Hakim juga merujuk kes Abdul Karim Kalapadathil Kutti lwn. Farisya Moideen Kutty ${ }^{38}$ di mana mahkamah Rayuan Syariah Wilayah Persekutuan telah memutuskan bahawa tempoh empat belas (14) hari untuk memfailkan rayuan diambil kira dari tarikh penghakiman itu sampai kepada pengetahuan pihak perayu jika beliau tidak hadir pada tarikh penghakiman diumumkan. Ini kerana jika pemakaian seksyen 139 (4) Akta Tatacara Mal Mahkamah Syariah (Wilayah-wilayah Persekutuan) secara ketat, maka akan menyebabkan ketidakadilan. Hal ini berikutan seksyen tersebut mengkehendaki notis

37 Aziah Abdul Aziz lwn. Azmi Abdul Aziz [2013] JH 36/1.

38 Abdul Karim Kalapadathil Kutti lwn. Farisya Moideen Kutty [2013] Kes Mal Rayuan No: 14000-077-0059-2012 yang diputuskan pada 25 Jun 2013. 
rayuan difailkan dalam tempoh empat belas (14) hari dari tarikh penghakiman diumumkan tanpa menyebut sama ada penghakiman diumumkan dengan atau tanpa kehadiran pihak satu lagi.

Oleh kerana mudarat perlanjutan tempoh masa dalam kes rayuan terhadap fasakh lebih besar kepada pihak isteri, maka mahkamah tidak boleh sewenangwenangnya melanjutkan tempoh masa memfailkan rayuan kerana keputusan mahkamah akan dijadikan hujah dalam kes-kes terkemudian terutamanya kes yang melibatkan isteri yang telah pun berkahwin lain. Justeru, pihak perayu berkewajipan untuk meyakinkan mahkamah bahawa kelewatan selama sepuluh (10) bulan selepas beliau mengetahui Mahkamah Rendah Syariah memfasakhkan nikahnya. Alasan bahawa pihak perayu berada dalam keadaan keliru dan dilema merupakan alasan yang remeh dan tidak dapat diterima oleh mahkamah kerana ianya adalah tidak munasabah untuk pihak perayu membiarkan keadaan dirinya berada dalam dilema dan keliru selama sepuluh (10) bulan. Keadaan tersebut menunjukkan pihak perayu tidak bersungguhsungguh dan sengaja melengah-lengahkan.

Berdasarkan kes tersebut, penulis ingin menjelaskan bahawa sekiranya pihak yang tidak berpuas hati ingin membuat rayuan terhadap kes fasakh, mereka hendaklah membuat rayuan ke mahkamah yang lebih tinggi sama ada ke Mahkamah Tinggi Syariah atau Mahkamah Rayuan Syariah dalam tempoh empat belas (14) hari selepas penghakiman atau perintah dimeterai oleh mahkamah. Sekiranya tempoh untuk merayu tersebut telah tamat, maka pihak-pihak yang ingin merayu hendaklah membuat satu permohonan lain iaitu permohonan lanjutan tempoh masa dan setelah permohonan tersebut diluluskan oleh pihak mahkamah, maka pihak-pihak barulah dibenarkan untuk memfailkan notis rayuan ke mahkamah.

\section{KESIMPULAN}

Berdasarkan kepada perbahasan di atas, dapat disimpulkan bahawa pensyariatan fasakh di dalam Islam adalah bertujuan untuk mengimbangi hak wanita sebagai kaum yang lemah dan seringkali menjadi mangsa kepada lelaki yang mengambil kesempatan di atas kelemahan tersebut. Namun begitu, pihak isteri tidak boleh menyalahgunakan tuntutan fasakh untuk membebaskan diri dari tanggungjawab dalam perkahwinan apabila tanggungjawab tersebut telah ditunaikan oleh suami dengan sewajarnya. Manakala suami pula tidak boleh menyalahgunakan ikatan perkahwinan dengan melayan isteri secara melampaui batas-batas hukum yang telah ditetapkan oleh Allah SWT. 
Oleh yang demikian, pemeliharaan hak ke atas isteri dari hukum Syarak hendaklah ditadbir dengan baik oleh pihak yang berwajib agar para isteri tidak mengalami kesukaran tambahan apabila terpaksa melalui pelbagai kerenah yang bersifat teknikal dan prosedur sewaktu mengemukakan tuntutan fasakh di Mahkamah Syariah. Berdasarkan kepada peruntukan-peruntukan dan amalan-amalan di atas, penulis membuat kesimpulan bahawa prosedur dan tatacara tuntutan dan perbicaraan kes fasakh yang digunapakai kini masih perlu diperbaiki dengan meminda dan menambah beberapa peruntukan yang ada dalam Enakmen Tatacara Mal. Antara peruntukan yang dimaksudkan adalah seperti meringkaskan proses penyampaian di Bahagian VI, kaedah memberikan keterangan yang melibatkan isu afidavit, proses pra bicara dan perbicaraan berterusan di Bahagian XIV dan memendekkan tempoh masa rayuan di Bahagian XVII.

\section{RUJUKAN}

Abdul Monir Yaacob (2000). Undang-undang Keluarga Islam dan Wanita di Negara-Negara ASEAN, cet.ke-2. Kuala Terengganu: Yayasan Islam Terengganu.

Ahmad Hidayat Buang (2003). "Faktor-Faktor Penangguhan Kes-Kes Mal di Mahkamah Syariah di Malaysia Berasaskan Kepada Fail-Fail Kes Mahkamah," (Kertas Kerja Pembentangan, Seminar Penyelidikan Projek Keberkesanan Mahakamah Syariah, Kuala Lumpur, 21 Oktober 2003).

Ahmad Ibrahim (1978). "Fasakh for Failure to Maintain," Journal of Malaysian and Comparative Law, vol. 5.

Amalina Husain (1993). "Kedudukan Fasakh dalam Enakmen Keluarga Islam Kelantan Darul Naim: Satu Penilaian," (Latihan Ilmiah, Jabatan Syariah Undang-undang, Bahagian Pengajian Syariah, Akademi Pengajian Islam, Universiti Malaya).

Arip Ameran (2000). "Tuntutan Fasakh: Kajian Khusus di Mahkamah Syariah Sarawak (Bahagian Kuching) 1990-1998," (Latihan Ilmiah, Jabatan Syariah Undang-undang, Bahagian Pengajian Syariah, Akademi Pengajian Islam, Universiti Malaya).

Hadrah Layabo (2002). “Alasan-Alasan Pembubaran Perkahwinan Melalui Fasakh: Satu Kajian Kes di Mahkamah Syariah Kota Kinabalu, Negeri Sabah," (Latihan Ilmiah, Jabatan Syariah Undang-undang, Bahagian Pengajian Syariah, Akademi Pengajian Islam, Universiti Malaya). 
Mahmud Saedon Awang Othman (1990). "Acara Mal Mahkamah Syariah: Suatu Analisis," Kanun Jurnal Undang-Undang Malaysia, vol. 2, no. 4, 1-24.

Mehrun Siraj (1989). "The Development and Implementation of Syariah Laws in Malaysia: The Position of Muslim Women," dalam Workshop Shariah and Civil Laws: Developments and Implementations and the Position of Muslim Women.

Mohd Nadzri Haji Abdul Rahman Ibrahim (2013). Undang-Undang Tatacara Mal Mahkamah Syariah: Prinsip dan Amalan. Kuala Lumpur: Anugerah Cekal Sdn. Bhd.

Mohd Raziff Tan Sri Zahir (1998). Tuntutan-tuntutan Mal di Mahkamah Syariah dari Aspek Amalan, ed. Ahmad Hidayat Buang. Kuala Lumpur: Penerbit Universiti Malaya.

Narizan Abdul Rahman (2005). "Isu-isu dan Masalah Perundangan Mahkamah Syariah," (Kertas Kerja Penyelidikan IRPA, Balai Ilmu, Akademi Pengajian Islam, Universiti Malaya, 30 Ogos 2005).

Nik Roslina Raja Ismail (1999). "Kajian Perbandingan Jangkamasa yang diambil Untuk Menyelesaikan Kes-kes Berhubung Perceraian serta Kekerapan Penangguhan Kes di antara Mahkamah Syariah dan Mahkamah Sivil," (Disertasi Diploma, Institut Pentadbiran Awam Negara).

Noor Hayati Aripin (1992). "Peruntukan Fasakh dalam Undang-Undang Keluarga Islam di Malaysia: Satu Rujukan Kepada Enakmen UndangUndang Keluarga Islam Pahang 1987," (Latihan Ilmiah, Jabatan Syariah Undang-undang, Bahagian Pengajian Syariah, Akademi Pengajian Islam, Universiti Malaya).

Norizan Othman (2008). "Kes Perceraian Secara Fasakh kerana Dharar di Mahkamah Syariah Melaka dari tahun 1995-2000," (Disertasi Sarjana, Jabatan Syariah dan Undang-Undang, Akademi Pengajian Islam, Universiti Malaya).

Nurhidayah Muhammad Hashim (2001). "Pembubaran Perkahwinan Secara Fasakh: Satu Kajian Kes di Mahkamah Syariah Wilayah Persekutuan Kuala Lumpur," (Disertasi Sarjana, Jabatan Syariah dan UndangUndang, Akademi Pengajian Islam, Universiti Malaya).

Rafidah Sulaiman (2003). "Pembuktian di dalam Kes Perceraian Fasakh: Kajian Kes di Mahkamah Syariah Petaling Jaya," (Latihan Ilmiah, Jabatan Syariah Undang-undang, Bahagian Pengajian Syariah, Akademi Pengajian Islam, Universiti Malaya). 
Raihanah Abdullah (1997). "Alasan Membubarkan Perkahwinan Melalui Fasakh,” Jurnal Syariah, vol. 5, no. 1, 51-62.

Raihanah Abdullah (2009). "Penangguhan Kes di Mahkamah Syariah: Cabaran dan Penyelesaian”, Jurnal Syariah, vol. 17, no. 1, 17-19.

Salmah Ahmad (1999). "Analisis Kes-kes Fasakh di Mahkamah Syariah Wilayah Persekutuan," (Latihan Ilmiah, Jabatan Syariah Undangundang, Bahagian Pengajian Syariah, Akademi Pengajian Islam, Universiti Malaya).

Sheikh Ghazali Haji Abdul Rahman (2005). "Pengalaman Mahkamah Shariah Mengenai Isu dan Permasalahan Undang-Undang" (Kertas kerja dibentangkan di Konvensyen Kehakiman dan Guaman Syarie anjuran Kolej Universiti Islam Malaysia di Hotel Pan Pacific KLIA Sepang, Selangor, pada 13-14 September 2005).

Suwaid Tapah (2005). Undang-undang Mal Syariah: Mahkamah Syariah di Malaysia, Pencapaian dan Cabaran, ed. Ahmad Hidayat Buang. Kuala Lumpur: Penerbit Universiti Malaya.

Raihanah Abdullah (1997). "Alasan Membubarkan Perkahwinan Melalui Fasakh,” Jurnal Syariah, vol. 5, no. 1.

Stephen, J. (1886). A Digest of The Law of Evidence. London: William Clowes $\&$ Sons.

Wan Haslina Wan Ab Kadir (2007). "Pembuktian Berdasarkan Qarinah dalam kes Fasakh di Mahkamah Rendah Syariah Kota Bharu," (Latihan Ilmiah, Jabatan Syariah Undang-undang, Bahagian Pengajian Syariah, Akademi Pengajian Islam, Universiti Malaya).

Zaleha Kamaruddin (2001). "Wanita dan Kelewatan Kes di Mahkamah Syariah: Antara Realiti dan Persepsi," dalam Wanita dan Perundangan Islam, ed. Raihanah Abdullah. Selangor: Ilmiah Publishers.

Zaliha Safee (2000). "Pembuktian di dalam Kes Perceraian Fasakh: Satu Kajian Kes di Mahkamah Syariah Wilayah Persekutuan," (Latihan Ilmiah, Jabatan Syariah Undang-undang, Bahagian Pengajian Syariah, Akademi Pengajian Islam, Universiti Malaya).

\section{Senarai Statut}

Akta Tatacara Mal Mahkamah Syariah (Wilayah-Wilayah Persekutuan) 1998 (Akta 585).

Akta Undang-Undang Keluarga Islam (Wilayah-wilayah Persekutuan) 1984 (Akta 303).

Arahan Amalan JKSM Tahun 2005, No.1. 
Enakmen Tatacara Mal Mahkamah Syariah Negeri Selangor 2003 (Enakmen 4).

\section{Senarai Kes}

Abdul Karim Kalapadathil Kutti lwn. Farisya Moideen Kutty [2013] Kes Mal Rayuan No: 14000-077-0059-2012 yang diputuskan pada 25 Jun 2013.

Ahmad Redzuan Mohd Hanapiah lwn. Jane Betty Tasmini @ NorAinah Abdullah [2014] JH 38/1, 44-46.

Aziah Abdul Aziz lwn. Azmi Abdul Aziz [2013] JH 36/1.

Hafizah Indra Abdullah lwn. Jamaluddin Eusoff [2006] 22/1.

Hairun Mohd Sharif lwn. Omar Mohd Nor [1990] JH 8/2.

Hamzah Omar lwn. Haslina Halim [2014] JH 38/2.

Joan Mary Sulaiman lwn. Sulaiman Haji Musa [1995] JH 10/1.

Kelthom lwn. Ismail [1995] Permohonan No: MTSTR 41/010/1/95 di hadapan Yang Arif Hakim Haji Ismail Yahya pada 19 April 1995 di Mahkamah Tinggi Syariah Kuala Terengganu.

Noor Liza Haji Latif lwn. Muhammad Asri Ismail [2006] JH 22/2.

Radzi Abdullah lwn. Nursyaireen Radzi dan Seorang Yang Lain [2013] JH $36 / 1$.

Rosnani Hassan Abdullah lwn. San Ahmed Abu Zarin [1989] Kes Mal Bil: 85/88, Mahkamah Tinggi Syariah Negeri Melaka.

Siti Hasnah Jantan lwn. Saharum Shariff [2013] 1 CLJ (Sya), 189-193.

Zulriana Zamri lwn. Mohd Shu'aib Haji Ishak [2014] JH 38/1. 